Dudding. The honorary secretary is Mr. S. Harris, and the registered office is at 54 New Broad Street, London, E.C.2. 6.6

\section{Atomic Scientists Association}

The July issue of Atgmic Scientists News is notable in that for the first tire the journal is bound in an attractive, colou, Ar Cover, a considerable improvement in ance. The contents of the issue include a r jort $\mathrm{f}$ the annual general meeting, held on June 25 , of the Atomic Scientists Association, and a survey by a Birmingham study group of the problem of atomic weapons and civil defence. At the annual meeting the following officers were elected : President, Prof. R. E. Peierls ; Executive Vice-President, Dr. K. Lonsdale; Honorary General Secretary, Dr. F. C. Champion; Honorary Treasurer, Dr. T. G. Pickavance; Editor of the News, Dr. J. L. Michiels; Librarian, Dr. W. D. Allen. Because of a reserve of $£ 1,600$, largely built up from profits made on the sale of the guide to the "Atom Train", the financial position of the Association was considered sound, though an annual deficit of some $£ 300$ is being incurred owing to the considerable secretarial expense and the cost of maintenance of the London office of the Association.

The president in his report referred to some of the problems which had occupied the attention of the Council, in particular, the likely consequences of an atomic attack on Great Britain and the steps that could be taken to minimize them; measures taken against Communists and other persons associated with extremist political organisations in the Civil Service; and misleading press reports on atomic energy problems. The report of the Birmingham study group is interesting. Rescue work, radiation dangers, fire-fighting and the efficiency of shelters are discussed. The two main conclusions arrived at are : first, that in an atom bomb attack on a town in Great Britain the number of casualties would be so large that if only a small fraction of these could be prevented or rescued, many lives would be saved; and second, that there would be less chance of learning from experience than there was in the Second World War, and thus the air-raid precautions organisation, including the necessary public propaganda, must be complete before the event of the first raid.

\section{Research Council for the Linoleum Industry}

THE linoleum and felt-base floor-covering industry has set up a Research Council with the approval and support of the Department of Scientific and Industrial Research. Linoleum manufacture offers wide scope for research, the endowment of which will form the initial policy of the Council. Problems include the oxidation of the basic raw material, linseed oil, its processing and compounding and calendering on to hessian backing, and also the manufacture and development of the special paints used for linoleum. Arrangements have already been made with the Paint Research Station for work on some of the problems of drying oils, linseed oil, gels and sealing coats for saturated felts. An information service has been set up, a central library started and a survey of patents relating to the industry begun. Dr. S. R. W. Martin has been appointed superintendent of research, and a programme of fundamental research has been agreed. The secretary is Mr. A. G. Vaughan. The membership of the Research Council includes substantially the whole industry, and the headquarters are at Roxburghe House, 273-287 Regent Street, London, W.1.

\section{British Trust for Social Studies}

THE purpose of the British Trust for Social Studies is to enoburage social research of scientific and practical importance by making small grants, not less than $£ 20$, for particular projects to persons, other than full-time research workers, who have the opportunity for social observation and wish to record their impressions and work up the material in their own spare time. The recipient of a grant will be expected to produce within an agreed period a paper of $5,000-$ 7,000 words setting out the results of the research in a way that can be understood by intelligent non. technical readers. The papers so produced will be at the disposition of the Trust for publication. Application forms and further information can be obtained, by post only, from Miss Marion Nuttall, Secretary, British Trust for Social Studies, 16 Queen Anne's Gate, London, S.W.1.

\section{Announcements}

THE Mapagers of the Royal Institution have accepted/fith regret the resignation of Prof. E. K. Rideal, whose duties will terminate on December 31, 1949. Prof. E. N. da C. Andrade, Quain professor of physics in the University of London, has accepted an invitation to become director in the Royal Institution, resident professor and director of the Davy Faraday Research Laboratory. He will assume his duties on January 1, 1950.

Prof. K. JAather, professor of genetics in the University/of Birmingham, Prof. S. Zuckerman, professer of anatomy and physiology in the University of Birmingham and chairman of the Panel on Inports Substitution, and Prof. G. F. Marrian, professor of chemistry in relation to medicine in the University of Edinburgh, have been appointed members of the Agricultural Research Council in succession to Prof. T. G. B. Osborn, Sir John Simonsen and Mr. W. J. Wright, whose terms of office have expired.

Prof. J. D. Bernal will speak on "Science in the U.S.S.R. To-day" at the Beaver Hall, Mansion House, London, E.C.4, on October 15 at 2.30 p.m. The lecture has been arranged by the Science Section of the Society for Cultural Relations with the U.S.S.R., 14 Kensington Square, London, W.8, from which tickets are available.

THE Mríseum of the History of Science, Old Ashmolean Building, Oxford, which began in 1924 as the Lewis Evans Collection, is to be re-opened by the Earl of Crawford and Balcarres on October 11 at 2.30 p.m.

Biologists everywhere will learn with regret that the laboratories of Flatters and Garnett, Ltd., of Manchester, were seriously damaged by fire on the night of September 17-18. The firm's entire stock of some thirty to forty thousand microscopical preparations was destroyed, as well as much valuable equipment. The Skeleton and Dissection Department has also suffered severely, and much preserved botanical material has been lost. The bulk of the firm's lantern slide negatives has been saved, although the stock of finished slides has been destroyed. The Chemical Department and Instrument Works are unaffected, and the office and warehouse at 309 Oxford Road, Manchester 13, are functioning. Messrs. Flatters and Garnett state that work on the rebuilding of the burnt-out portion has already commenced, and temporary accommodation has been found for the departments affected. 